\title{
Bodies in the Archive
}

OFF AND ON FOR FIFTEEN YEARS I traveled the country to research the life and work of the nineteenth-century physician S. Weir Mitchell. Mitchell is best known as the creator of the rest cure to treat hysteria and neurasthenia, but his wide-ranging interests led him to explore many other areas of medicine and literature. His groundbreaking work with rattlesnake venom earned him an international reputation, and his work with gunshot wounds, burning pain, and phantom limbs during the U.S. Civil War won him the title of the "Father of American Neurology." Mitchell also possessed an impressive facility with language, and he found great pleasure in writing medical books, poetry, and novels. And, like so many of his contemporaries, he wrote countless letters. In 1990 The College of Physicians of Philadelphia acquired the S. Weir Mitchell Papers: twenty boxes that include family papers, a 300-page unpublished autobiography, and extensive correspondence. Several of Mitchell's friends were prominent figures, and important correspondence can be found in their collections as well.

Since completing a biography of Mitchell in 2012, I have taken some time to reflect upon my experience in the many libraries and archives that I visited. I think back on my presence in those spaces and the many librarians who helped me along the way. I think of the bodies represented in the letters, books, and manuscripts I studied, particularly those of Mitchell—as a young boy, medical student, Civil War surgeon, father, physician, poet, and prominent citizen of Philadelphia. Opening the folders, seeing his handwriting, touching the envelopes, stationery and ink, and organizing hundreds of letters chronologically, I listened to his voice and watched the stages of his life evolve and take shape. Looking back, I realize that reading correspondence and looking at photographs on a computer screen at home would have been an utterly different experience. In this essay, based on my years of research and travel, I want to argue for the importance of physical presence in the actual space of the archive. Working on a flat screen in one's office or study, as important and efficient as it may be, cannot replace embodied experience.

For me, stepping into the medical archive felt like an adventure. With a $\mathrm{PhD}$ in British Literature and Feminist Theory, I had been trained to do interdisciplinary

1. An earlier version of this paper was given at the 225th Anniversary of the Historical Medical Library of The College of Physicians of Philadelphia, in December 2013. 
research, close reading, and critical analysis. I was in the habit of utilizing literature, history, and theory in my teaching and writing. I had read theorists like Mikhail Bakhtin, Michel Foucault, and Judith Butler and studied their concepts of the dialogic imagination, discourse theory, and performance. While working on Charlotte Brontë, George Eliot, and Virginia Woolf, one thing led to another. Woolf's experiences with doctors and the rest cure led me to Charlotte Perkins Gilman's short story "The Yellow Wall-Paper," which quickly led me to Mitchell. Equipped with the sensibilities of a literary critic and with Mitchell as my guide, I began to explore the relation between nineteenth-century medicine and women's health and careers.

Work in the Medical Humanities involves wide reading and the integration of a number of disciplines such as the History of Medicine, Social Science, Women's Studies, history, critical theory, and the study of literature. My work in the Medical Humanities formally began in the summer of 1994 when, as a Visiting Scholar at the Institute for Research on Women at Rutgers University, I read all the articles about women in the British Medical Journal from 1880-1920. These were hard copies of the journal with the physicality of weight, smell, sound, touch, and texture. I often found myself flipping through the pages and reading articles on various topics before I settled down to the business at hand. The pages were aging and the print was a little difficult to readnothing like working with the clean text-searchable PDF scans that are available online.

At Rutgers I saw flyers announcing two conferences in England the following summer, a George Eliot Conference at the University of Warwick in Coventry and the following week, a Gilman Conference at the University of Liverpool. I made plans to present papers at both, then rent a flat in London for a month and work at the Wellcome Library. After the Liverpool conference, I took the train to London, and the next day I went to the Wellcome Library with a letter of introduction from the president of my college. I worked in that elegant environment for four weeks and rarely left the building, examining first editions of eighteenth-century gynecological atlases and reading old medical textbooks.

I had come across the name "Hunter" at Rutgers while reading a speech given by the president of the British Medical Association in 1886 on the education of women. At the Wellcome Library I looked up John and William Hunter, and eventually found my way to William Hunter's greatest single contribution to medicine: his remarkable and costly gynecological atlas, The Anatomy of the Human Gravid Uterus. This atlas was twenty-four years in the making, and during those years Hunter oversaw the work of four artists and at least sixteen engravers. The artists drew from the dead bodies of thirteen pregnant women. Finally published in 1774, the atlas contains thirty-four plates representing the first "from life" illustrations of the interiority of pregnant bodies. 


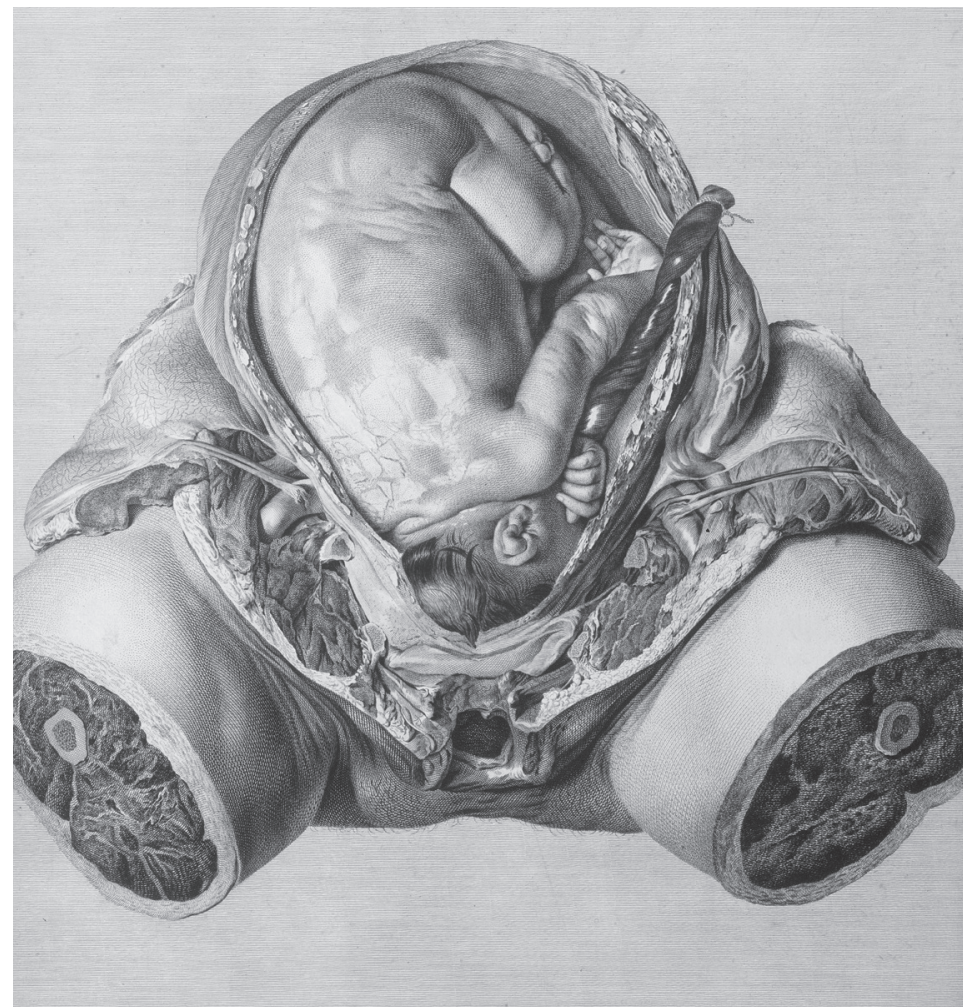

Figure 1. William Hunter. The Anatomy of the Human Gravid Uterus. Plate VI. 1774. Courtesy of Wellcome Library, London.

My experiences getting to London, opening this atlas for the first time, and struggling with ambivalent feelings about the beauty of the engravings and the butchery of the bodies illustrates the analytical complexity of working in the Medical Humanities. Childbirth was an especially perilous business at the time, but, still, how and where did Hunter obtain these bodies? Who were these women? Although the questions merely suggest some of the layers of meaning and underlying relations of power that made the atlas possible, the focus shifts from thinking about Hunter's great contribution to medicine to the lives of the thirteen women, obscure and headless, who are immortalized in these pages. Foucault calls such obscure archival lives "strange poems," fragments surviving because of their encounter with power and giving "rise to a certain effect of beauty mixed with dread."2

At the Wellcome Library, I also examined first editions of William Smellie's 1754 obstetrical atlas containing thirty-nine plates and Charles Jenty's 1757 atlas containing six mezzotint plates as a way of comparison with Hunter's atlas. I read some

2. Michel Foucault, "Lives of Infamous Men," in Power: Essential Works of Foucault, 1954-1984, Vol. 3, ed. James D. Faubion (New York: The New Press, 2001), 157, 159. 
of the books listed on Jefferson Medical College's recommended reading list for Obstetrics and Diseases of Women and Children during the years that Mitchell attended, including Velpeau and Churchill on midwifery, Charles D. Meigs's edition of Colombat de l'Isere on Diseases of Women, and Meigs on Females, their Diseases and Remedies.

I returned to Kansas City with seventeen slides from the gynecological atlases and notes over the medical books. I went immediately to the Clendening History of Medicine Library at the University of Kansas Medical Center to read Mitchell's first book, Researches upon the Venom of the Rattlesnake. While I was there, the director told me about the fairly new acquisition of the S. Weir Mitchell Papers purchased in 1990 by The College of Physicians of Philadelphia. She told me about the College's Francis Clark Wood Institute Fellowships and suggested that I apply. And, thus, the following summer I found my way to the oldest independent medical library in the United States and twenty boxes of Mitchell materials that few scholars had yet examined.

The main point I hope to make with my story is the importance of my physical presence in these archives, where I engaged with the librarians, directors, archivists, and materials. Each time I would leave with recommendations, notes, copies, photos, and transcriptions. On several occasions a particular librarian would surprise me with materials of which I was unaware. These individuals, trained in information technologies with specialist knowledge of their collections and the wider field, offered me personalized help in a way that the internet never could. If, for example, I had read Mitchell's Researches upon the Venom of the Rattlesnake online, I might not have heard about the College's acquisition of the Mitchell Papers. All along the way it has been through such contacts and conversations that I imagined the next step.

It would be difficult to overstate the contributions that librarians have made to my research. And the adventure continued. As a recipient of a fellowship from the National Endowment for the Humanities and Agency for Healthcare Research and Quality, I spent a year traveling extensively to read Mitchell's correspondence at twenty other libraries, such places as the Beinecke Library, the Sterling Memorial Library, and the Cushing/Whitney Medical Library at Yale, the Francis A. Countway Library of Medicine, the Houghton Library, and the Schlesinger Library at Harvard, the Historical Society of Pennsylvania, the University of Pennsylvania, the New York Public Library, and the Osler Library at McGill University in Montreal. I made a particularly worthwhile road trip to the Bernard Becker Medical Library at Washington University in St. Louis to examine a copy of Felice Fontana's 1787 Treatise on the Venom of the Viper, an important influence on Mitchell's work. The rare book librarian had located several related works, and these fascinating old 
materials on serpents and vipers along with Fontana's treatise provided a context for understanding Mitchell's experimentation with venomous snakes.

On one of my return trips to Philadelphia, the College archivist suggested that I examine six sets of before-and-after photographs of rest cure patients, photographs which I had not come across on earlier trips. ${ }^{3}$ The London physician William S. Playfair had mailed these photographs to Mitchell as visual evidence of the power of the rest cure to transform and save lives. Even though I had been reading about rest cure patients for years, I still remember opening the folder and seeing these before-and-after photographs for the first time.
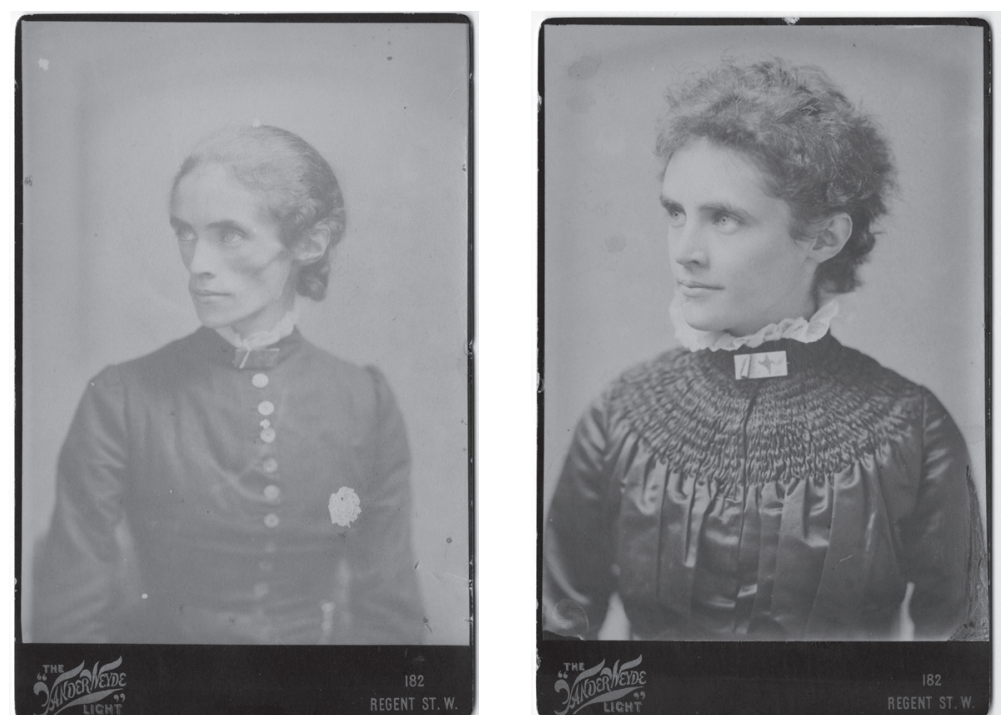

Figure 2: Before-and-After Photographs of a Rest Cure Patient. 1882. MSS 2/0001-01. Courtesy of The College of Physicians of Philadelphia.

Hands-on experiences like my work with the first edition of Hunter's atlas, Fontana's treatise, and Playfair's photographs breathe life into a project. In the archives such visceral experiences engage my attention in ways a flat screen cannot.

Writing about the technological transformations taking place, Jacques Derrida states that "archivization produces as much as it records the event." Archival technology "no longer determines, will never have determined, merely the moment of the conservational recording, but rather the very institution of the archivable event. It conditions not only the form or the structure that prints, but the printed content of the printing: the pressure of the printing, the impression, before the divi-

3. W.S. Playfair, Portraits of Cases of Rest Treatment, 9 August 1882, MSS 2/0001-01, The College of Physicians of Philadelphia. 
sion between the printed and the printer [original emphasis]."4 What is gained working online — convenience, speed, sanitation, magnification—cannot stand in or make up for the energy, alertness, pressure, and impressions that are lost. Bodily sensations fuel perception, tension, and pleasure and mix with and deepen comprehension to create a more richly evolved final product. I would argue that the final product, whether in the History of Science, Biography, or Philosophy, is different if materials and images are accessed on a flat screen. How can a process that casts off physical presence, the book as material object, and the touch of raw materials inspire the historian, novelist, poet, and film maker in the same corporeal way?

Our time has been called the "era of the archive," a time when the collection of documents and the creation of archives has increased dramatically. Fascination with the idea of the archive pervades the Humanities where scholars revise its meaning as both a physical place and a metaphor. Derrida writes that the archive"a quasi-infinity of layers, of archival strata that are at once superimposed, overprinted, and enveloped in each other" - comes into being through loss and embodies the feverish human search for origins. ${ }^{6}$ As a central concept in Foucault's work, the archive represents memory as an open-ended, future-oriented process where archival material continues to return in unpredictable and transformative ways. ${ }^{7}$ No small part of this fascination has resulted in works of literature, often called archive fiction, that explore the detective work and feelings of frustration and exhilaration surrounding archival research.

In Umberto Eco's novel The Name of the Rose, for example, the plot unfolds in an Italian abbey where the head librarian is the second most powerful person in the abbey. Only he and his assistant have access to the library, the largest in Christendom. The year is 1329, and Eco describes the library as "the place of a long, centuries-old murmuring, and imperceptible dialogue between one parchment and another, a living thing, a receptacle of powers not to be ruled by a human mind, a treasure of secrets emanated by many minds, surviving the death of those who had produced them or had been their conveyors." ${ }^{8}$ Several of the monks hunger for the knowledge in these books and die horrible deaths as a consequence of their desire. The library's catalogue is a "feast" of titles, and when Brother William of Baskerville visits, "at every title he discovered he let out exclamations of happiness" and felt "highly excited and titillated. In short, for him every book was like

4. Jacques Derrida, Archive Fever: A Freudian Impression, trans. Eric Prenowitz (Chicago: University of Chicago Press, 1996), 17, 18.

5. Jeffrey Wallen, "The Lure of the Archive: The Atlas Project of Walid Raad," Comparative Critical Studies 8.2-3 (2011): 277.

6. Derrida, Archive Fever, 22.

7. Michael Sheringham, "Michel Foucault, Pierre Rivière and the Archival Imaginary," Comparative Critical Studies 8.2-3 (2011): 253.

8. Umberto Eco, The Name of the Rose, trans. William Weaver (Orlando: Harcourt, Inc., 1983), 286. 
a fabulous animal that he was meeting in a strange land." Eco explains that "what the temptation of adultery is for laymen and the yearning for riches is for secular ecclesiastics, the seduction of knowledge is for monks." ${ }^{\prime \prime}$ Far different from what is sometimes thought of as an uneventful and tedious place, Eco's library is a "living thing" where books arouse intense bodily sensations of dread, sublimity, danger, and desire.

In 1908 Daniel Wright Kittredge published The Memoirs of a Failure. In the book the narrator receives a coffin-like box, and one fragment in the box tells the story of a professor who could read the minds of the dead. He gets an Egyptian mummy to talk, and he takes the narrator to a cemetery where he inserts tubes into graves and listens to the corpses speak. Max Saunders explains that this tale's "fantasy of telephoning the dead allegorizes the fantasy that textual archival remains can be made to speak their truth. ${ }^{\prime 10}$ But is it a fantasy? While archival fiction is usually more realistic than Eco's gothic novel or Kittredge's wild tale, it often concerns the same desire to seek origins and resurrect past lives. These literary works set in motion the major motifs of archival culture and politics, providing a way to acknowledge and analyze mutual experiences that scholars, librarians, and curators share. Archival narratives make sense of an old and venerable undertaking through representing such aspects as intellectual craving and curiosity, the loneliness of the pursuit, the hunt for missing books and letters, the exploitation of private papers, and the sublime moments of discovery. Plots frequently revolve around letters that are hidden, sealed, lost, or burned or, when found, contain shocking revelations.

In the summer of 1887 Henry James wrote The Aspern Papers. The plot of this novella is based on the true story of a Boston sea-captain who attempted to get hold of some letters of Shelley's and Byron's by becoming Clair Clairmont's lodger. In James's retelling, the letters are in the possession of two older women living in Venice. The narrator, who is Jeffrey Aspern's biographer, states, "I'm sorry for it, but there's no baseness I wouldn't commit for Jeffrey Aspern's sake." He also makes it clear that he finds these old women provincial and pathetic. Still, he finds great pleasure in being in the same house with the letters, "sacred relics" as he calls them, and feels that they make his life "continuous, in a fashion, with the illustrious life they had touched at the other end. I lost myself in this satisfaction...." On more than one occasion he displays an indecent appetite for these letters, but in the end, when one of the women has died and the other agrees to hand over the letters if he will marry her, he runs from the house horrified. When he wakes the next morning, however, the letters are "more precious than ever" and "a positive ferocity" had come into his need to acquire them. But it is too late. Miss Tina has burned the

9. Ibid., 310, 183.

10. Max Saunders, "Archive Fiction," Comparative Critical Studies 8.2-3 (2011): 184, 185. 
letters and tells him, "Yes; what was I to keep them for? I burnt them last night, one by one, in the kitchen.... It took a long time - there were so many."11

Twenty years later, ill and depressed, Henry James gathered forty years of correspondence, notebooks, and manuscripts in his garden at Lamb House, and he burned them. Leon Edel writes, "He was ruthless. A great Anglo-American literary archive perished on that day." ${ }^{12}$ What was James thinking as he watched these papers-including thousands of letters written to him - consumed by the flames? What did he want to destroy? Watching the flames, feeling the heat, smelling the smoke and ashes - such a lavish scene is hardly imaginable in an electronic age.

The value of archival material plays a major role in another novel, Impassioned Clay, published by Stevie Davies in 1999. The plot represents the shift in historiography taking place around the same time where micro-events and seemingly ordinary individuals became desirable topics of research. Foucault writes that for "a long time, only the actions of great men had merited being told without mockery: only blood, birth, and exploit gave a right to history." But then a change came about, and an "unending hum began to be heard, the sound of the discourse that delivered individual variations of behavior... The commonplace ceased to belong to silence..." ${ }^{13}$ In order to capture the look and feel of this shift in Impassioned Clay, Davies replaces Henry James's old Venetian palazzina with a modern library. Rather than the life of a famous nineteenth-century poet, the obscure life of a sixteenthcentury Quaker woman becomes the subject of research. And a young female graduate student replaces James's scheming biographer.

Olivia, the narrator of Impassioned Clay, becomes obsessed with skeletal remains excavated in the backyard of her childhood home. The skeleton belonged to a woman who wore a scold's bridle and an iron crown when she died. Her jaw had been crushed and her neck had been broken. Stunned by the violence of this woman's death, Olivia decides to study history in order to investigate what happened and deliver the woman "from her long silence." She does research at the Bodleian where antiquarian volumes become her passion. She experiences that strange sense of time where the past becomes her present, and "persons erupted from innards of books as the spines creaked open; and the dead spoke to me, with such vehement voices that when I looked up, my contemporaries seemed blurred and dull." ${ }^{14}$

In search of the skeleton's identity, Olivia makes her way to numerous other archives, including the John Rylands University Library and Chetham's Library in

11. Henry James, The Aspern Papers and Other Stories (Oxford: Oxford Press, 2000), 7, 28, $94,96$.

12. Leon Edel, Henry James The Master: 1901-1916 (New York: Avon Books, 1972), 437, 142.

13. Foucault, "Lives of Infamous Men," 169.

14. Stevie Davies, Impassioned Clay (London: The Women’s Press, 1999), 68, 32. 
Manchester, The Friends Library in London, the Chester Public Record Office, and archives in Cardiff and Lancaster. She experiences a number of sublime moments, when she first discovers the skeleton's name, for example, and when she discovers a letter carefully sealed in the last page of a diary. With scissors from her briefcase, she slits the vertical join and out slides a double sheet covered in minuscule handwriting on both sides. ${ }^{15}$

Thomas Wright, an Oscar Wilde scholar, related a recent experience he had at UCLA's Clark Library that is strikingly similar to Davies's fictitious account.

Among the twelve books from Wilde's personal library at the Clark Library, Wright found a copy of an annual report entitled The Eighty Club 1890. The club, formed in 1880, was an influential political organization consisting of around $250 \mathrm{mem}$ bers who were mainly MPs, journalists, and solicitors. But at the time of the find, Wright had not heard of the club, and he wondered why Wilde had kept the report. When he turned to the back of the volume, the answer "almost literally" fell out and onto the desk - a dated receipt for the club's annual subscription fee made out to "Oscar Wilde." Wright notes that Wilde's political activism has, oddly enough, been neglected or gone unnoticed by other scholars, and this small slip of paper has led to Wright's groundbreaking investigation of Wilde's political activities and his Liberal position on Irish Home Rule. ${ }^{16}$

In Impassioned Clay Davies represents the thrill of such dramatic finds. She describes the elegant and sometimes vault-like atmosphere of libraries, the disappointment of records misplaced or destroyed, the interesting behavior of some librarians, and the eccentric behavior of some scholars. Olivia says, "I recognized my own neurosis in a woman who snatched and cradled to her breast a pile of folios. Opening one on a charcoal-grey foam pad, she reverently laid a lead chain like prayer beads over the pages to prevent damage by live fingers. Everyone watched." ${ }^{17}$ As a result of Olivia's extensive research, the voices in the letters begin to speak to her. In this way, the author tells the micro-histories of renegade Quaker women like Martha Simmonds and Mary Howgill who led radical lives publishing tracts, filibustering male leaders, and claiming spiritual authority for women in the sixteenth century. ${ }^{18}$

Letters also play a lead role in Martha Cooley's The Archivist, published just one year before Impassioned Clay. The letters at the heart of this novel are the twelve boxes or approximately 1100 letters from T. S. Eliot to Emily Hale sequestered at Princeton until January 2020. By weaving this historical event throughout the plot,

15. Ibid., 93-94.

16. Thomas Wright, "Party Political Animal: Oscar Wilde, Gladstonian Liberal and Eighty Club Member,” Times Literary Supplement, June 6, 2014, 13-15.

17. Davies, Impassioned Clay, 140.

18. Ibid., 223-28. 
Cooley excites the reader's interest and curiosity. Who gets to read Eliot's letters first? What difference will they make in understanding his work and his complicated relationships with Vivienne Haigh-Wood and Emily Hale? And, underlying these explicit questions, how will emails, texts, and tweets replace the letter writing of the past?

Much of Cooley's novel is told from the point of view of the archivist, Matt Lane. Like Olivia in Impassioned Clay, Matt develops a love of books as a child. About his first trip to the Library of Congress, he writes, "I'd read many descriptions of the vast collection, but I was unprepared for the beauty of the building itself." 19 This is an important point. Many archives are beautiful places. To what extent does working in such an elegant atmosphere affect the research and knowledge production? What will be the fate of these refined and aesthetically pleasing spaces in an electronic age?

It is unlikely in the foreseeable future that all the personal papers, especially of more obscure figures, will be online. However, even if all materials were accessible online eliminating the necessity to travel, a persuasive case can be made that the effects on scholarship and publication would be profound. Warwick Gould writes that "there is always something new to be found in the original object" and "content and its material embodiment cannot be separated unless one wishes to pretend that content is inherently portable and unnuanced by materiality." He also notes that electronic surrogates are edited documents, and because of this human intervention, there will be surrogate error. ${ }^{20}$ Phyllis Franklin writes that "since the shape, feel, designs, and illustrations of books have affected, and continue to affect, readers' responses (some of which have been recorded in the margins of pages) access to the physical forms in which texts from the past have appeared is a fundamental part of informed reading...."21 Original materials can convey significant information through their actual structure, weight, color, texture, ink, borders, and marginalia. As edited documents, electronic surrogates lose some of this information.

Derrida writes that the technological upheaval now occurring affects the very structures of our psychic apparatus in terms of spatial architecture, economy of speed, and processing of space and the passage of time. Taking psychoanalysis as an example, he asks in what ways the whole field was determined by a particular state of communication and archivization. Doing what he calls "retrospective science fiction," he speculates how the current geo-techno-logical shocks would have

19. Martha Cooley, The Archivist (Boston: Little, Brown and Co., 1998), 12.

20. Warwick Gould, "My Infinite Library," Libraries and Culture 37.1 (Winter 2002): 65-68.

21. Phyllis Franklin, "The Importance of Primary Records,” in Who Wants Yesterday's Papers? Essays on the Research Value of Printed Materials in the Digital Age, ed. Yvonne Carignan, et al. (Lanham, MD: Scarecrow Press, 2005), 119. 
made the landscape of psychoanalysis unrecognizable. If Freud and his contemporaries instead of writing thousands of letters had access to computers, printers, faxes, television, teleconferences and above all email, it would not be a question of simple continuous progress in representation but rather an entirely different logic. Derrida writes, "This archival earthquake would not have limited its effects to the secondary recording, to the printing and to the conservation of the history of psychoanalysis. It would have transformed this history from top to bottom and in the most initial inside of its production, in its very events... [T] he technical structure of the archiving archive also determines the structure of the archivable content even in its very coming into existence and in its relationship to the future" [original emphasis]. ${ }^{22}$

In spite of or perhaps because of the digital revolution, the idea of the "archive" creates considerable excitement these days. It is just possible, in thinking about the contemporary enthusiasm for archives, that the technological revolution has coincidentally created a reconsideration and a deeper understanding of the physical archive as a unique place of creative exchange and interaction rather than a location for information storage, safekeeping, and retrieval. Of course, it should not be a question of one or the other. Together, physical and digital archives provide exciting possibilities for research, writing, and editing.

Still, I have been speaking about one part of the process to argue that work online, as important as it is, is not interchangeable with or equivalent to research performed in an archive. Work on a flat screen cannot replace or substitute for physical presence and interaction with the librarians and the materials. Major support for travel to the physical space of libraries and archives should remain a priority. Rather than thinking nostalgically, institutions should continue to maintain and celebrate this vital human endeavor in order to sustain its dynamic and transformative contribution to the production of meaning. 